Fall 2000

\title{
Notes on David Krell's The Good European
}

David B. Allison

SUNY StonyBrook, nosillad@suffolk.lib.ny.us

Follow this and additional works at: https://fordham.bepress.com/phil_research

Part of the Continental Philosophy Commons, Esthetics Commons, French and Francophone Language and Literature Commons, and the Other German Language and Literature Commons

\section{Recommended Citation}

Allison, David B., "Notes on David Krell's The Good European" (2000). Research Resources. 25.

https://fordham.bepress.com/phil_research/25

This Article is brought to you for free and open access by the Hermeneutic and Phenomenological Philosophies of Science at DigitalResearch@Fordham. It has been accepted for inclusion in Research Resources by an authorized administrator of DigitalResearch@Fordham.

For more information, please contact considine@fordham.edu. 


\section{Notes on David Krell's The Good European}

\section{David B. Allison}

So many things come together so beautifully in The Good European, it is hard to imagine not being moved by it. ${ }^{1}$ I just want to discuss what kind of book this is and, more specifically, I'd like to try to explain, in some detail, just how this work is able to achieve the remarkably performative effect that it has on the reader - at least on this reader. At the outset, it should be said that The Good European is an oversized, illustrated book - a well-known genre although it is quite unusual to find an example of such work devoted to the life and thought of a philosopher. More simply stated, it is an illustrated biog raphy of Nietzsche and it focuses on the principal sites of Nietzsche's farflung residences and travel destinations, places where he lived and worked. The design and layout of the text is a particularly effective conjunction of photographic images by Donald Bates and written text by David Krell that generates a remarkable reader-dynamic, drawing the reader, or observer, into proximate contact with Nietzsche's own experienced world. It's this dynamic relation of image and word that I'd like to explore here.

When Nietzsche tried the impossible - to talk about the relation between music and words, in his 1871 essay of the same title - he ultimately found that the only way one could make sense of such a relation was to talk about one's own personal experience of the mood that the musical performance engendered in oneself. From The Birth of Tragedy on, Nietzsche would constantly invoke the reader to appeal to his or her own experience of music, so as to evoke the parallel feeling in the reader - who would hopefully, then, invest this feeling in the appreciation of Nietzsche's written text. First, he attempted to bring about an affective provocation and then urged the reader to make a projective investment, an emotional cathexis of sorts. Nietzsche would draw upon every artistic and stylistic device from antique poetry and tragedy, from Aristotle right through contemporary opera - invoking a wide range of rhetorical and figurative usage, the employment of hyperbole, of striking imagery, frequent use of analogy and metaphor, as well as elements of musicality, psychological projection, association, reminiscence, etc. He would invoke all these stylistic devices to induce the reader to come

New Nietzsche Studies, Volume Four: Nos. 1 \& 2, Summer/Fall 2000, pp. 201-212.

(C) 2000 Nietzsche Society. ISSN 10910239. 
to an understanding of his work, his reflections, his temperament, and even of himself. It is an extremely difficult thing to do well, especially for one who claimed to have written in blood.

To induce. That is, to lead into. A variety of cognate words and concepts are built around its root, ducere - to lead. To induce, to adduce, produce, seduce, reduce, educe, introduce, come to mind. Tinkers to Evers to Chance. To lead, or to draw the reader in, suggests more of a strategy compounded by indirection than by instruction or by simple directive, much less, by a neat, efficiently causal, procedure.

The French writer, Nathalie Sarraute, attempted such a writing of indirection to induce her readers to enter the dramatic situations of her characters by means of what she called "invisible actions" - tropisms - that would skirt the more normally obvious narrative techniques, such as plot development and character evolution. She says,

What I tried to do was to show certain inner "movements," by which I had long been attracted; in fact, I might even say that, ever since I was a child, these movements, which are bidden under the commonplace, harmless appearances of every instant of our lives, had stuck and held my attention. In this domain, my first impressions go back very far. These movements, of which we are hardly cognizant, slip through us on the frontiers of consciousness in the form of undefinable, extremely rapid sensations. They bide behind our gestures, beneath the words we speak, the feelings we manifest, are aw are of experiencing, and able to define. They seemed... to me to constitute the secret source of our existence, in what might be called its nascent state. And since, while we are performing them, no words express them, not even those of the interior monologue - for they develop and pass through us very rapidly in the form of frequently very sharp, brief sensations, without our perceiving clearly what they are - it was not possible to communicate them to the reader otherwise than by means of equivalent images that would make him experience analogous sensations. It was also necesary to make them break up and spread out in the consciousness of the reader the way a slow-motion film does. Time was no longer the time of real life, but of a hugely amplified present... these movements, which are inherent in everybody and can take place in anybody, and any moment.... I called Tropisms...I gave them this name because of their spontaneous, irrestible, instinctive nature, similar to that of the movements made by certain living 
organisms under the influence of outside stimuli, such as light or heat. $^{2}$

As her friend Jean-Paul Sartre remarked, concerning his own "logic of seduction," "One must see without being seen." But, of course one does see and is seen, in any "situation." And the site specificity of such an engagement, whereby in viewing a landscape, for example, one has the remarkable sense that it is co-constituting the viewer, and leading him on, drawing him in, is perhaps best observed by another of Nathalie Sarraute's friends, MerleauPonty. For him, vision is essentially conjoined with the motor-project in our pre-objective interaction with the world, such that my perspective on the world is always a position-taking with regard to it, that is, within it. I have the orientation I presently enjoy, here, with its field of possible action and motility, precisely because I am looking there, where everything discloses itself to my view. In the course of my motor projects, my active projections into the world, my own lived self is carved out as this bodily schema, around which the world is in turn oriented. I am orientation, yet I am world as well. I am, as Merleau-Ponty remarks, enmeshed in the world, I literally cohere with things. The landscape reverberates itself in me. And this is my first relation to, my being with, things. Recall his brief quote from Cezanne, in "Cezanne's Doubt": "The landscape thinks itself in me, and I am its consciousness." Hence, Merleau-Ponty's account of the situated self is depicted somewhat enigmatically:

It is not a self through transparence, like thought, which only thinks its object by assimilating it, by constituting it, by transforming it into thought. [Rather] It is a self through confusion, narcissism, through inberence of the one who sees in that which he sees, and through inherence of sensing in the sensed - a self, therefore, that is caught up in things...

That Nietzsche himself was so thoroughly enmeshed and caught up in the world of his work and travels, that he felt so thoroughly continuous and contiguous with the very elements that configured his landscape, he literally identified himself in their terms. The ever-changing landscapes became his own Epicurean garden, composed of his mountains, his seas, lakes, forest trails and clouds - and like Descartes, he would repair to this garden in search of solitude, stillness, to cultivate his tree of his philosophy for the new, the good Europeans - and, like Descartes, he would turn to Ovid for his motto: bene vixit bene qui latuit - he lives well who hides himself well. ${ }^{5}$ He was constantly aware of the barometric pressure and the ambient static electricity, the climatic temperature, the frequency and monthly amounts of 
rainfall and days of full sun; his residences were always described to his correspondents in terms of their relation to the layout of the village or town, to the period architecture of their buildings, to the surrounding mountain peaks and adjoining bodies of water. Nietzsche mentions several times in his correspondence that he had a list of some 50 conditions - almost exclusively environmental - that had to be met before he could live in a particular area. He was perhaps most seduced by the brilliant light of the upper Engadine, its resplendent snowfields and glaciers, its glistening lakes - as well as by the mists that enshrouded Venice, the narrow and cobbled streets of Genoa, the boulevards, plazas, and the gallerias of Turin, the gardens and the Promenade des Anglais of Nice, etc. All this is graphically educed through his more than 1250 letters and drafts, as well as in his prose works and poetry. Every day it was physically possible - especially after his Basel years - he would walk for hours on end, by the sea, along mountain paths, through alpine meadows and forests, through, and usually out of, his favorite cities and towns.

It is the remarkable way by which we are led - drawn into - the appreciation of Nietzsche's world, through the elegant play between image and text, eye and mind, that constitutes the real virtue of this work, The Good European.

Several elements in the composition of The Good European contribute to its extraordinarily seductive power. First of all, there is an architectural - even symphonic - character to the narrative development of the work.

The overture to The Good European is strikingly sounded in the Introduction by Krell's forthright discussion of the Death of God and its absolute centrality to Nietzsche's thought and life-work. And this theme will be quickly sundered and sketched out according to two countermoments or movements that are broadly characteristic of Nietzsche's life and thought. Krell's narrative follows out Nietzsche's own dealings with the baroque interplay of these two, quite dissonant, but significantly organizing, moments - carefully following Nietzsche's painful attem pts to achieve some liveable, thinkable, harmonious resolution. The first broad motif is the Heraclitean play of the innocence of becoming, which is already, and palpably, there - which constitutes nature and buman natue - and must be felt, experienced by all, in the absence of the old, angry God. Second, there is the darker side - the seemingly inevitable replacement of the old God by a newly awakened and fiercely driven ideological nationalism. The lighter side will be most dramatically expressed in Krell's text through the majestic photographs of the European landscape garden - some 243 remarkable images - of its alpine heights, the brilliant mountain flowers, its forest and 
meadow bowers, where Agave, Ino, Autonoe and her Bacchantes shed their doeskins amid springs of milk and honey, and of sparkling water - perhaps like the celebrated spring waters of Panna, in the beautiful Mugello valley, in northern Tuscany, or up on the heights of Monte Pana, far above Santa Christina, in the Val Gardena of the Alto Adige, welcoming a bountiful spring after descending from the Brenner Pass. This effulgent lightness and joy would also grace Nietzsche on his walk up the Monte Sacro, above Lake Orta, in the spring of 1882, and like Lou Salomé, they would follow Nietzsche to the meadow and forest paths outside Tautenberg, in Thuringia. This would be a blessed six weeks that Nietzsche would lovingly eternalize in a moment of love - if it only could abide. But perhaps the minor chord was there already - in his drafts for Zarathustra, beginning in the late winter and early spring of 1883 , when Nietzsche seemed to project the figure of Lou Salomé into one of the major characters of the work then in progress - the only significant role to be assinged to a woman. This would be a feminized Pan, an eroticized figure named Pana, who according to three different drafts would kill Zarathustra - and in three different ways: first, by sending him to follow Empedocles back into the bowels of the earth in Mt. Aetna, and then by making him die of laughter; finally, simply by stabbing Zarathustra to death. ${ }^{6}$

But the real theme of darkness resides in the second movement, Nietzsche's early awareness that the old God would not easily die. As the elderly Saint lamented in his forest, in the case of the gods, death is merely a prejudice. Krell pointedly draws us into Nietzsche's horrified apprehension that the old God had become ideologically resurrected as a savage form of modern nationalism, with its hydra-head of xenophobia, antisemitism, plutocratic greed, and class hatred - all hardened avatars of the old, universal church, only this time, emboldened by the prosperity of modern science and fueled by a mighty industrial revolution. The shadows materialized for Nietzsche through his first-hand experience of the mechanized, industrial warfare of the Franco-Prussian War - a war Nietzsche knew could only be the Bismarkian herald of the unspeakable century to come. All the personal bitterness and pietistic ressentiment developing for two millenia - now bereft of their stabilizing, if not fundamentally mendacious, ontotheological grounds - would be recast blindly and hatefully into the armed legions of so many divisive European nation states. This will to destruction, nihilism, weariness, decadence, the all-so-many interconnected notions that Nietzsche struggled with in this domain, notions that would lead straight to despair and ruination - or, what he would simply call "woe" in Zarathustra — all this had to be thought 
through, anticipated, and countered, on new grounds. It would have to be overcome by a willed unity of Good Europeans, and perhaps this might even have to come at an enormous human expense. But nonetheless, this crystalizes into Nietzsche's oft-repeated "task," a major motif resonant throughout his life, and expertly conveyed throughout Krell's text, The Good European. This task, framed against a volatile Europe of discredited valueformations, reeling into a thoughtless future, would prove to be the arm ature of Nietzsche's lifew ork, one that positively begged for completion against all odds. Ultimately, he knew, however, that the task would be Europe's own: Nietzsche's task would be to articulate it.

Yet, as Krell points out in the Introduction, this is not particularly conceived of in political terms; it will be a personal task - it will be a work of art to rebuild Europe from its foundations - just as Descartes had posed his Discourse on Method as a model, not for the explicit political project of reformation, but as a personal model - and certainly Zarathustra would be an example of this - as a personal history or fable.

Krell deals with this life project admirably in the Introduction, such that it will be projected throughout the subsequent chapters - as well as to sound out the baser chords of the persistent illnesses that would shadow this solitary wanderer right to the end of his life.

At which point Krell breaks and returns to the simple elements of Nietzsche's beginnings, his own foundations - family, childhood, and early education in Chapter One, "Beginnings and Ends," and again ending with the end, Nietzsche's own descent into an increasingly painful void. The largely biographical trajectory of the text, accompanied by a series of black and white documentary photos, extends from Röcken and Naumburg, through Bonn, the Franco-Prussian War, to Leipzig and Basel, before leaping ahead to the later collapse in Turin - in the very shadow of the Holy Shroud - and on to Jena, Naumburg and Weimar. The narrativebiographical writing of each chapter is guided in large part by Krell's own Baedeker, the faithful Curt Paul Janz, and is punctuated in its detail by reminiscences from Nietzsche's friends and many acquaintainces. ' What lends real drama to this substructure of each chapter is the striking introduction of each chapter's complement, or rather, supplement: brilliantly colored landscape scenes, given in the form of what Krell terms a "portfolio."

The break in tone, from the black and white illustrations - whether dating from the period itself, or Bates' recent photographs of the sites Nietzsche visited, lived in, and wrote from - to Bates' dramatically composed color photos is extremely effective: not only visually and emotionally, because of their contrast in color - from sepia archive to 
overpowering, often romantically sublime, landscape photography - but also because they force the reader to pause and rethink, to retentionally recuperate, the itinerary that had just preceeded the portfolio, in the narrativebiog raphical first part of each chapter. This return to what one has just read, is thus a recursivity which literally reanimates the life and landscape with the vitality and vibrancy of chromaticism, and by Nietzsche's own silent voice - i.e., each of the photos in the second, "portfolio" division of the chapter are accompanied by relevant passages from his published work, his journals, or letters.

The design elements of this portfolio format are enhanced by

1) The brilliance of color

2) A softness of hue

3) A markedly different, and varying size, format

4) The architectural composition of the landscape photographs is elegant and dramatic

5) By and large, by a complete absence of human subjects in the pictures themselves

One has to pause, one is effectively compelled to pause, completely absorbed by these pictures - as Nathalie Sarraute says, they spread out in almost a suspension of lived time - suspending precisely what was narratively conveyed in the first part of each chapter: the seriality of successive events, conversations, itineraries planned and followed, sites visited, projects in progress, constant and repetitive reflections on Nietzsche's developing situations of employment, family, personal relationships, recurring bouts of painful illness and depression, the constant fretting about being disturbed in his work by the imprecation of friends and visitors, the lack of close intellectual equals with whom he could discuss his work, and the pain of isolation he needed in order to be able to work at all. All these concerns which amount to synchronicity itself, and which constitute the very life of the biographical narrative - are effectively disrupted, suspended, broken, by the intrusion of these self-standingly dramatic landscape photographs. Of course, these pictures are meant to provoke those analogous sensations, they are meant to evoke a parallel mood, and to draw you into the landscape as Nietzsche himself had been so seduced by such prodigious beauty.

One could say that Krell almost sentimentally manipulates the reader through the use of these dramatic jump-cuts, these sharp breaks in perspective, tone, and mood. The end of each narrative section invariably ends on a note of tristesse, or loneliness, of impending tragedy or persistent despair, only to be dramatically reversed by the explosion of natural beauty and 
vitality of the "portfolio" illustrations. Doubtless, one could say that, but it is nonetheless flawlessly accomplished. The book's designer should get the celebrated visit from Ed McMahon, with the publisher's sweepstakes grand prize, for so graciously structuring and orchestrating these shifts of intensity. Truly inspired by the breath of Nietzsche's accompanying voice and visually charged by the light of the immediately broken-off narrative, the pictures resonate with vitality.

Many of us, too, will be drawn into this work by dint of our own familiarity with Nietzsche's writing, his correspondence, his associations, but also due to the skillful evocation of our own experience with some of these sites depicted in The Good European.

Let me mention just one anecdote that occurred to me, one that was triggered by seeing the beautiful images taken of the Nietzsche path - le chemin de Nietzsche - that leads from Eze-sur-mer to Eze-village, just to the east of Nice, heading towards Monte Carlo. Dominique Janicaud drove me out to an unbelieveably ramshackle house in Eze-sur-mer, situated right at the base of the cliff that comes down from Eze-village on the Middle Corniche. The cliff itself rises above Eze-village, and goes all the way to the top of the mountain, where there is an old ruined castle - an ancient chateau-fort - crumbling away in remote isolation. This is the last line of the French Alps as they descend south and vanish into the sea - the Alpes Maritimes. The place we stopped at looked like some vile amalgam of an Appalachian shack - a completely broken down, dishevelled farm house on a dirt cowpath - and an industrial dump, somewhere around the oil refineries out by Secaucus, New Jersey, or the remnants of a scrap-heap by the rail line in Gary, Indiana. Three mangy, howling, junk-yard dogs really foul curs - on chains; a broken down fence, overturned, burned-out rusty vehicles - a couple of old Renaults and Simcas, an archaic Citroen; a couple of those dirt-brown, deux-chevaux trucks on their sides, rotted out, no tires; what seemed to be a tropical efflorescence of long-discarded water heaters, oil tanks, bent-up fifty-gallon oildrums, all orange from fires and rust, spilling over with crap, twenty or so old truck tires lounging in the weeds; tin cans, broken pallets, plastic buckets, shards of torn, black plastic sheeting manically flailing in the trees, and so on. You get the picture.

Why are we here? - I practically scream to Dominique, as we pretty well abandon the car in the broad smear of an outsized mud rut, right in the middle of all this litter and junk. Just wait, he says. We head into an impossible tangle of weeds, junk, vines, shaggy bushes, and trees, and there is the trail, the celebreated Nietzsche path. About 20 yards in, it climbs above the trees, and is fairly nestled in an angled ridge, ascending the cliff face. The 
stone steps and footstones are worn smooth, the landscape is quite steep, with one small meadow area giving into an elevated forest. There is one smallish stone house, or barn, that we pass by on the way up to the Middle Corniche, but that's all. We are in the middle of a French national park, completely protected from development - a rarity on the Riveria. Getting in to the full sun, the trail is bordered with wild rosemary, wild roses, and thyme, petites marguerites - like daisies - as well as clumps of jaunier and lavender. A few gnarled trees strikingly loom out of the cliff face and frame an extraordinary view of Cap Ferrat and the Bay of Angels - leading over to Nice, and of a sea so blue that only blood could be redder. It's about an hour's walk up to Eze-village, every step as fantastically beautiful as any landscape I've seen.

The village of Eze is a small, walled-in medieval town, and Dominique explains to me that, in the early Middle Ages, fairly well everyone lived at the base of the mountain, occupied as they were with fishing and coastal trading. They constructed this path, concealing it from sight from below, from the sea, in the folds of the ridges and escarpments, so that when the pirates and warlords would periodically loot and pillage along the French littoral, the residents could escape, unseen, to their fortified mountain retreat. It was a pleasure to know that Nietzsche would come out practically every day from Nice by train, climb up the path, and pause here and there to take some notes for Zarathustra - likewise peregrinating from the motley village below up to his mountain retreat. Spectacularly beautiful.

Dominique and I grabbed a cup of coffee and a petit muscadet in one of the now quaint tourist cafes in Eze - accessible now by the road that hugs the middle of the Alpes Maritimes, the Moyenne Corniche, i.e., the windy road that goes along the middle ledge of the cliff face. ${ }^{8}$ After the coffee, we slip back across the road, between two of those notorious boulders that line the edge of the Middle Corniche, to prevent cars from hurtling down the thousand foot drop to the base. On the way back down the path, one constantly has the Mediterranean in full sight, glistening and shimmering in the late afternoon sun, with a nice onshore breeze - drawing up the scent of the lavender, roses, the profusion of wildflowers, mixed in with the soft, gentle smell coming in off the sea. We pause by the stone structure and Dominique springs the surprise! Lets go in and have something cool to drink. And I am fairly well surprised - since we had not seen a single soul on the trail, either on the way up or down, and besides, the building looked unoccupied and completely isolated and abandoned, at first glance, on the way up. It was set about 20 or 30 feet off the trail, in a grove of olive trees, poplars, and some cyprus and cedars. Turning the corner of the southeast- 
facing wall we saw the door, and improbably, it had a small sign on it: café. No tables and chairs outside, just a couple of small windows, higher up on the stone walls - much like those small pavilions the WPA used to make in State Parks, during the Depression - for forest wardens to live in, or to be used as small bathhouses: a couple of spartan showers, sinks and toilets for the hikers or bathers. It was made of local limestone, breccia, from the adjoining cliff face and rubble.

Inside, there was a bar to the right - the usual zinc, maybe 15 feet long. Three or four sets of cafe tables and chairs in the middle, and the WCs on the left - mesdames and messieurs, respectively. Fellow was behind the bar, wiping off a glass - almost obsessively so, for quite a while. Get it clean, really clean! He paused, turned to us, and in a rather laconic, but somewhat labored and low voice, said "bonjour," — "b'jour" — almost as if he were speaking to us - there was no one else in the place, however.

He was on the short side, maybe five-four or five, featureless face, little Poirot eyeglasses, rather broad shoulders, a bit stocky, short-sleeved offwhite shirt and the classic blue tablier apron, which practically every rural peasant wears over his clothes when doing chores. Most barmen in the countryside wear them this way, with the top part up, looped over the neck. We stand up to the bar and order a couple of well-deserved glasses of beer - the temperature outside was about eighty or so, coming down from eighty-five. The beer was delicious.

I looked around the place and it looked pretty much like the café-bars one still finds in the back-country rural areas — in La France Profonde — for peasants and farmers, rural factory workers and artisans. A little tired from the sun and the hike, and a bit talked-out at this point, I start fumbling around with the cardboard coaster, thinking it will tout Ancre Beer or Kronenbourg, only to see that there is a direct quote from Nietzsche printed on it. The coaster read, "The German spirit has been killed by a diet composed entirely of beer, newspapers, and Wagner's music." On closer inspection, I notice that practically every object in the place has a phrase glued on or painted on to it - in conjunction with its conventional function, but drawn from something Nietzsche had written, regarding such use or function. Above the sink in the mens room, for example, was a Nietzsche quote enjoining one to wash and bathe frequently. Over the urinal was another Nietzsche quote about drinking plenty of water to improve one's digestion and keeping oneself unpolluted. One of the chairs quoted a remark about the perfect condition of the benches on the footpaths around Tautenberg. The inside of the entry door was a quote urging one to walk on 
mountain trails for good exercise. The tables were labelled with quotes, the coat rack, the hat rack - in fact, everything was.

Oddly, no picture of Nietzsche. The walls were bare, stuccoed. There was something a bit evasive about the guy - he wasn't the kind to look quite straight at you, but rather, on the oblique. He made me think of one of those characters Sartre talks about in Nausea, out there in Bouville. Or one of Camus' rather vague criminals in The Fall. I approached him and politely inquired if he were an adept of Nietzsche, and as he replied, I thought it was Peter Lorre flinching in the movie, M. Yes, he said, he made a livelihood as a sailor in the merchant navy when he was younger, and he happened upon one of Nietzsche's books in a used book store, in Marseilles. He said he read it ten or twelve times on his next voyage - I think it was The Gay Science, Joyful Wisdom - and he said his life was immediately transfigured. He then went on to read everything he could find by Nietzsche on his long ocean voyages, and that alone made his life worth living. When he retired from the merchant fleet, he was determined to do something in Nietzsche's honor - however simple, and in his own personal way. He set out to follow Nietzsche's itinerary in Germany, Switzerland, Italy, and France, and the only building that somehow graced Nietzsche's presence and that was for sale and affordable was this - an abandoned grenier, a small, onestoried stone barn/goat-shed. As we were leaving, he whispered, almost conspiratorily, "I call it the Nietzsche café." Not a single person on the way back down - on a beautiful, sunny day in July, top of the tourist season, on the French Riviera. Not a single indication at the base of the trail or at the top of the trail that there even was a trail.

About a week later, I ran into the playwright, Samuel Beckett - of all people - in a store on the rue Soufflot, just down from the Panthéon, in Paris. I thought, "Who better?" - maybe Harold Pinter or Ionesco? - to relate this story to than Beckett himself. We started to talk - he was quite gracious and friendly, really affable, even with that great hatchet face of his and the Kurt Jurgen eyes. But then the salesclerk asked him to pay for the three pairs of socks and undershorts, and the moment pretty well evaporated. We said goodby. About five years later, I heard that an immense forest fire - they were ravaging the south of France just a few years ago - had scoured the mountain face above Eze-sur-mer, and had forced the evacuation of Eze-village for almost a week, until the blaze had finally been put out.

I asked Dave Krell, when The Good European first appeared, if the Nietzsche café was still there when he and Don Bates had photographed the now-green Nietzsche path. He said there's no one there and that he didn't 
see any café - nor, for that matter, did he see any other Nietzsche adepts on the chemin de Nietzsche that day, either.

Again, so many things come together so beautifully in The Good European, it is hard to imagine not being moved by it.

\section{Acknowledgments}

This text was originally presented at the 1998 annual meeting of the Nietzsche Society at the University of Colorado in Denver.

\section{Endnotes}

1. David F. Krell and Donald L. Bates, The Good European: Nietzsche's Work Sites in Word and Image (Chicago: The University of Chicago Press, 1997), 266 pp.

2. Nathalie Sarraute, Tropisms, Eng. tr., Maria Jolas (New York: Braziller, 1963), pp.v-vi. Emphasis added.

3. Maurice Merleau-Ponty, "Cezanne's Doubt," in Sense and Non-Sense, Eng. tr., Hubert \& Patricia Dreyfus (Evanston: Northwestern Univ. Press, 1964), p. 17. Emphasis added.

4. Maurice Merleau-Ponty, "Eye and Mind," in The Primacy of Perception, ed., James Edie, Eng. tr., Carleton Dallery (Evanston: Northwestern Univ., 1964), pp. 162-3. Emphasis added.

5. For a particularly elegant philosophical account of the garden and its place in landscape architecture, see Allen S. Weiss, Unnatural Horizons: Paradox and Contradiction in Landscape Architecture (New York: Princeton Architectural Press, 1998), especially Chapter Four, "In Praise of Anachronism: Garden as Gesamtkunstwerk," pp. 108-153.

6. For an extended discussion of Pana, Lou Salomé, and Empedocles, see D. Allison, Reading the New Nietzsche (Lanham: Rowman \& Littlefield, 2000), Chap. III, "Thus Spoke Zarathustra."

7. Curt Paul Janz, Friedrich Nietzsche Biographie, 3 Vols. (Munich: Carl Hanser Verlag, 1978). See also, Sander L. Gilman, Conversations with Nietzsche: A Life in the Words of His Contemporaries, Eng. tr., David J. Parent (New York: Oxford University Press, 1987).

8. "When we reached a certain elevation, French sentries blocked our steps, since the path to the fortified top of the mountain was off limits from that point on. A simple osteria was located on this level spot; wooden tables and benches stood under an arbor. We sat down amid the splendid mountain nature with our gaze directed, in picturesque variety, up at the rounded heights or down at the charming coast with its delightful bays, bordered by a luxuriant green wreath, out of which groups of houses gleamed forth like bright blossoms. There I tasted for the first time 'vermouth de Torino' poured by Nietzsche, whom the mistral had stirred up into a most excited mood, full of humorous ideas. The 'guarded mountain' was the starting point for a series of verses which bubbled out in great abundance ... It was no improvisation of a higher kind, just amusing, witty couplets, which showed me an unexpected Nietzsche" (Resa von Schirnhofer, "April 3-13, 1884," in Gilman, Conversations, p. 149). 